\title{
W.E. Butler, N.Yu. Erpyleva \\ Proceedings with the participation of foreign persons in international procedural law of Russia and Ukraine
}

\begin{abstract}
This article is dedicated to one of the most interesting aspects of International Procedural Law - litigation with participation of foreign persons. Authors focused on a comparative analysis of Russian and Ukrainian legislation concerning the regulation of international procedural relations. Article includes two paragraphs: the first one considers international jurisdiction of Russian arbitrazh courts and Ukrainian economic courts on commercial matters; the second one examines the recognition and enforcement of foreign judgments in commercial matters on the territory of Russia and Ukraine. Authors deeply scrutinized a wide range of legal documents including domestic legislation and international treaties embracing either bilateral Treaty between Russia and Ukraine on legal assistance and legal relations on civil, matrimonial and criminal matters, or multilateral international treaties of regional character in the framework of the CIS in order to show the convergences and divergences in Russian and Ukrainian law concerning participation of foreign persons in international commercial litigation.

Key words: International Procedural Law; International Civil Procedure; International Jurisdiction; Foreign Persons; International Commercial Litigation.
\end{abstract}

\section{Introduction}

$\mathrm{F}$ rom the time of the breakup of the Soviet Union and transformation of the republics, comprising the Soviet Union, into independent sovereign states, their common history called into existence some integration processes flowing on different levels and with different speed. All former Soviet republics, excluding the Baltic states, were involved in the process of political, economical and legal integration, insti-

BUTLER, William Elliott — B.A. (The American University); M.A. (Johns Hopkins University); J.D. (Harvard University); LL.M. (Academy University of Law, Russian Academy of Sciences); Ph.D. (Johns Hopkins University); LL.D. (London University); LL.D. honoris causa (Kiev University of Law); Foreign Member, National Academy of Sciences of Ukraine and National Academy of Legal Sciences of Ukraine; Corresponding Member, International Academy of Comparative Law; John Edward Fowler Distinguished Professor of Law and International Affairs, the Dickinson School of Law, Pennsylvania State University

201 Old Main, University Park, PA 16802 USA

(webakademik@aol.com)

ERPYLEVA, Natalia - LL.M. (University of London); Ph.D. (Moscow State University); S.J.D. (Russian Academy of Civil Service); Corresponding Member, International Academy of Comparative Law; Professor, the Head of the Department of Private International Law, Faculty of Law, National Research University "The Higher School of Economics"

20 Myasnitskaya street, 101000 Moscow, Russia

(natasha.erpyleva@rambler.ru) 
tutional forms of which are represented by regional international organizations. At the present time we can talk about three integration processes of multilateral character that take place within the limits of international communities, including the Commonwealth of Independent States (CIS) ${ }^{1}$, the Eurasian Economic Community (EurAsEC) ${ }^{2}$ and the Common Economic Space (CES) ${ }^{3}$.

Cooperation of states is dynamically developed within the EurAsEC that, in perspective, can be transformed into the Eurasian Union that is the most perfect form of economic integration ${ }^{4}$. Taking into account the above-mentioned, the examination of the legal systems of the states of the EurAsEC, is considered to be quite interesting and relevant. Along with this, the above-mentioned international organization cannot be examined separately from the CIS, that, in its turn, can be evaluated as "the laboratory of comparative jurisprudence"s. On the other hand, the Eurasian legal space exists. All member states are geographically close to each other, and in the legal sphere they are united by common legal heritage. They use common working legal language (Russian). They are united by long experience of cohabitation within the institutional model (the CIS). The problem here is

\footnotetext{
1 See EG Moyseev, 'Legal Basis for Establishment of the Commonwealth of Independent States and Its International Legal Status' (2010) 8 Eurasian Legal Journal; EG Moyseev, '20th Anniversary of the CIS - Hard Way to Eurasian Economic Integration' (2011) 9 Eurasian Legal Journal; DM Akulov, 'Eurasian Economic Integration within the Framework of the CIS (International Legal Aspects)' (2012) 5 Eurasian Legal Journal.

2 See YV Mishalchenko, 'Eurasian Economic Community: Up-to-date Status and Development Prospects' (2009) 7 Eurasian Legal Journal.

3 See VI Kamyshevsky, 'Some Aspects of Legal Groundwork for Establishment of the Customs Union and Common Economic Space within the Framework of the EurAsEC' (2010) 1 Eurasian Legal Journal; SN Yaryshev, 'Common and Unitary Economic Space of the EurAsEC' (2010) 2 Eurasian Legal Journal; YN Maleev and SN Yaryshev, 'Role of Subjects of the Russian Federation in the System of the Common Economic Space' (2011) 12 Eurasian Legal Journal.

4 See VI Kamyshevsky, 'From the EurAsEC to the Eurasian Union' (2011) 8 Eurasian Legal Journal; EG Moyseev, 'Perspectives for Establishment of the Eurasian Union' (2011) 11 Eurasian Legal Journal; VM Shumilov, 'Treaty on EAEC: Basis of Eurasian Integration' (2012) 5 Eurasian Legal Journal.

5 See WE Butler, 'Law Reform in the CIS' (1996) 1:1 Sudebnik 9-32.
}

how to correctly use this common legal space while attempting to adjust to harmonization of the relationship with the larger communities (WTO, EC, CE, OECD).

Without highly developed comparative law in the CIS member states the perspectives of the Eurasian legal space will remain rather vague. Comparative law is the important tool serving to choose the direction and regulating the speed of establishment of the legal community in the Eurasian legal space. Notwithstanding the nature of the sub-national law or regulations based on the international agreements, application of the comparative legal method and wisdom of comparative law are extremely important for the lawyers of the Eurasian legal space. Therein, comparative law for Russia is the medium-term research and investment in education, future dividends of which are uncountable ${ }^{6}$. The present article, devoted to consideration of some aspects of proceedings with the participation of foreign element in Russian and Ukrainian procedural law, is a succeeding step out of the set of articles conceived by the authors and related to comparative analysis of international civil procedures of the EurAsEC member states, after publication of joint works in this sphere related to Belorussia and Kyrgyzstan, and also after publication of the primary joint work in this sphere related to Ukraine ${ }^{7}$.

Choosing the institute of the proceedings with the participation of foreigners as the subject of the comparative research was stipulated by its growing role in the up-to-date environment, that is enabled by at least two circumstances: first, extension of involving of foreign element into economic life of Russia and Ukraine as an objective conformity of internationalization of business relations and, as

\footnotetext{
See WE Butler, 'Eurasian Legal Space - Laboratory of Comparative Jurisprudence' (2011) 7 Eurasian Legal Journal 6-9.

See WE Butler and NY Erpyleva, 'Proceedings with Participation of Foreign Persons in International Procedural Law of Russia and Belorussia (2005) 7 State and Law 31-41; WE Butler and NY Erpyleva, 'Proceedings with Participation of Foreign Persons in International Procedural Law of Russia and Ukraine: Innovation of Legal Regulation' (2011) 10 State and Law 54-64; WE Butler and NY Erpyleva, Proceedings with Participation of Foreign Persons in International Procedural Law of Russia and Kyrgyzstan (2012) 11 Legislation and Economics 43-61.
} 
a result, increase of the number of economic disputes with the foreign element (especially in connection with the establishment of the Customs Union of the EurAsEC, uniting Russia, Kazakhstan and Belorussia, and also accession of Russia to WTO in August 2012); second, rapid development of private international law in both states, including such important branch of law as the international civil procedure. The authors assume that comparative characteristic of the institute of proceedings with the participation of foreigners in Russian and Ukrainian legislation shall make a succeeding step in scientific conceptualization of one of the most important branches of private international law in both countries ${ }^{8}$.

\section{1) International Jurisdiction of Russian Arbitrazh Courts and Ukrainian Economic Courts in Cases with the Participation of Foreign Persons}

The jurisdiction of Russian arbitrazh courts over cases with the participation of foreign juridical persons and individual entrepreneurs is determined by Russian legislation of procedure, in this instance the Code of Arbitrazh Procedure of the Russian Federation of 24 July 2002, which entered into force on 1 September 2002, as amended of 22 April 2013 (hereinafter: CAP Russia) ${ }^{9}$. Russian arbitrazh courts, despite a seeming calque of terminology, have nothing to do with arbitration. They are an integral part of the Russian judicial system, together with the Russian federal courts of ordinary jurisdiction, but are not courts of ordinary jurisdiction (Article 4(3), Federal Constitutional Law on the legal system of the Russian Federation of 31 December 1996, as amended of 08 June $2012^{10}$; Article 1 of the Federal

\footnotetext{
This study concentrates upon proceedings with the participation of foreign persons in international economic disputes, that is, disputes linked with entrepreneurial and other economic activity by juridical persons and individual entrepreneurs. In Russia these disputes are resolved by way of an arbitrazh proceeding and in Ukraine by an economic court proceeding.

9 C3 РФ (2002), no. 30, item 3012; (2013), no. 17, item 2028.

10 C3 РФ (1997), no. 1, item 1; (2012), no. 24, item 3064.
}

Constitutional Law on the arbitrazh courts of the Russian Federation of 28 April 1995, as amended of 06 December $2011^{11}$ ).

Section V of the CAP Russia (Chapters 32 and 33) is devoted to a "Proceeding with Regard to Cases with Participation of Foreign Persons"12. In accordance with Article 254, foreign persons ${ }^{13}$ enjoy procedural rights and bear procedural duties equally with Russian organizations and citizens. Foreign persons have the right to bring an action in arbitrazh courts of the Russian Federation pursuant to the rules of particular jurisdiction and systemic jurisdiction in order to defend their violated or contested rights and legal interests in the sphere of entrepreneurial or other economic activity. Foreign persons participating in a case must submit evidence to the arbitrazh court confirming their legal

$11 \quad$ C3 РФ (1995), no. 18, item 1589; (2011), no. 50, item 7334. Both laws are translated in WE Butler, Russian Public Law (2nd edn, OUP 2009). On both systems of courts generally see WE Butler, Russian Law (3rd edn, OUP 2009) \$\$ 6.41.-6.68.

12 In present time in the science of private international law there is no generally accepted terminology for defining procedural jurisdiction on civil cases with participation of foreign persons. Usage of multiple expressions ("international particular jurisdiction", "jurisdiction", "general competence”, "international systemic jurisdiction" and etc.) causes in theory dramatic collisions: such, quite frequently, one and the same expression is used for defining different legal phenomenon by different researches (e.g. "jurisdiction"). And vice versa, one and the same legal phenomenon is described by different researches in different expressions (e.g. distribution of powers on consideration of civil cases between the courts of different states is defined by different researches as "international systemic jurisdiction", "international particular jurisdiction" and etc.) According to the opinion of Mamaev, the most appropriate expression for definition of distribution of powers on consideration of civil cases with participation of foreign persons between judicial and other organs of different states is "international procedural jurisdiction". In its turn, the unitary complex institution of international procedural jurisdiction will be divided into "international judicial jurisdiction", "international administrative jurisdiction", "international arbitral jurisdiction" and etc. Under international judicial jurisdiction, according to Mamaev, the following shall be meant: a range of competence of judicial organs of a particular state for resolution of a particular civil case, in other words, such institution that is in nowadays called "international systemic jurisdiction". See AA Mamaev, International Judicial Jurisdiction in Cross-border Civil Cases (Moscow 2008) 36-44. In the present article such expressions as "international jurisdiction" and "international systemic jurisdiction" are synonyms.

13 Foreign persons in Russian legislation is a term understood to mean foreign organizations, international organizations, foreign citizens, and stateless persons engaging in entrepreneurial and other activity. See Article 247(1), CAP Russia. 
status and the right to engage in entrepreneurial and other economic activity. If such evidence is not submitted, the arbitrazh court has the right at its own initiative to demand such evidence.

The jurisdiction of Ukrainian economic courts in cases with the participation of foreign juridical persons and entrepreneurs is established by economic procedure legislation, namely the Code of Economic Procedure of Ukraine of 6 November 1991, a new version of which was adopted on 6 December 2012 (hereinafter: CEP Ukraine) ${ }^{14}$. The Ukrainian economic courts are an integral part of the courts of ordinary jurisdiction of Ukraine specializing in the consideration of economic disputes ${ }^{15}$.

Under Article 1(1) of the CEP Ukraine, foreign subjects of economic management ${ }^{16}$ have the right to bring an action in economic courts according to the established particular jurisdiction over disputes for the defense of one's violated or contested rights and interests protected by a law, and also to take measures directed towards the prevention of violations of law. Foreign subjects of economic management (Article 123, CEP Ukraine) also have the same procedural rights and duties that subjects of economic management of Ukraine have, subject to exceptions established by a law or international treaty, consent to being binding on Ukraine has been given by the Supreme Rada of Ukraine.

Which term is more appropriate: "foreign persons" or the cumbersome "foreign subjects of economic management"? Each legal system struggles to cope with a "foreign ele-

\footnotetext{
14 Ведомости Верховной Рады Украины (1992), nо. 6, item 57; Официальный вестник Украины (2013), no. $1 / 58$, item 6 .

15 See Article 17(2) and 18(1), Law of Ukraine on Court Organization and the Status of Judges, of 7 July 2010, as amended of 2 October 2012. Ведомости Верховной Рады Украины (2010), по. 41-45, item 529; Официальный вестник Украины (2012), no. 81, item 3253.

16 The term "foreign subjects of economic management" is understood in Ukrainian legislation to mean foreign enterprises, institutions, organizations, and other juridical persons, and also foreign citizens engaging in entrepreneurial activity without the formation of a juridical person and who have acquired in the established procedure the status of a subject of entrepreneurial activity. See Article 1(1), CEP Ukraine.
}

ment" and each does so through the prism of its own legal experience rather than the realities of foreign structures. In the instance of the Russian Federation, "foreign persons" in fact encompasses natural and juridical persons, the former only if they engage in entrepreneurial activity, but the last which engage in "economic" activity that need not necessarily be entrepreneurial. This definition excludes legal entities which do not exist under Russian law but which may nonetheless need access to Russian courts and conceivably act as foreign investors in Russia (assuming they are not accidentally excluded). Examples are such legal entities as associations of persons that are not juridical persons (e.g., partnerships in England and the United States) or trusts ${ }^{17}$.

Moreover, they may be required in Russia to offer evidence to an arbitrazh court that they have confirmation of their "legal status" and the "right" to engage in entrepreneurial activity. It is symbolic of how far Russia is removed from the mentality of a market economy that it would require "evidence" of what in the United States and England is the natural right of every citizen - to engage in entrepreneurial activity without State registration, authorization, or permission. In logic, Russian law would need to demand the opposite confirmation that a citizen of those countries does not have the right to do so, and the difficulty would be that no official or institution in the United States or England would be in a position to certify such with respect to an individual or an association of persons.

The Ukrainian term "subjects" is, in principle, broader than the Russian term and could in principle encompass legal entities under foreign law that are not juridical persons. However, the definition offered by the CEP Ukraine is in substance similar to the Russian definition and narrower that the term actually used. "Subjects of law" would in principle extend to associations of persons and trusts, including those which engage in "economic management" as understood in

\footnotetext{
The extent to which a trust may be a juridical person or merely a legal entity may depend upon the particular features of the trust and the legal system in which it is formed. Our example has reference to those trusts which are plainly not juridical persons.
} 
Ukrainian legislation. The Ukrainian legislator, having selected a better term, undermined that choice by defining it too narrowly. The result in both Russia and Ukraine is to deprive the courts of jurisdiction and the foreign subjects of law concerned of the opportunity to have cases heard.

The Russian Federation has retained a provision first introduced during the Soviet ${ }^{18}$ era that retaliatory limitations might be introduced with respect to foreign persons of those foreign States in which special limitations have been introduced with respect to Russian organizations and citizens (Article 254(4), CAP Russia) ${ }^{19}$. The CAP Russia further authorizes, in principle, procedural privileges for foreign persons if an international treaty of the Russian Federation so provides (Article 254(1)).

The CEP Ukraine omits any mention of retorsion and does not presuppose the possibility of a more favorable procedural regime for foreign subjects of economic management that is accorded to Ukrainian organizations and citizens. It is of relevance that the CAP Russia designated the Government of the Russian Federation as the agency empowered to introduce procedural limitations on foreign persons by way of retorsion in the form of decrees. Since the CEP Ukraine does not mention retorsion at all, the potential possibility of relying upon retorsion as a principle of private international law is entirely unclear, as is the procedural form in which retorsion might be applied in Ukraine should that be deemed to be desirable or necessary.

The basic principles for establishing the subject-matter jurisdiction of Russian arbitrazh courts and Ukrainian economic courts with regard to international economic disputes are quite different respectively in the CAP Rus-

\footnotetext{
18 See Article 59, Fundamental Principles of Civil Procedure of the USSR and Union Republics, of 8 December 1961. Ведомости Верховного Совета СССР (1961), no. 50, item 526; transl. in WE Butler, The Soviet Legal System: Legislation and Documentation (OUP 1978) 447. Identical provisions were found in the Code of Civil Procedure of the union republics, including the RSFSR and Ukrainian SSR.

19 See PP Kolesov, 'Procedural Guarantees of the Legal Status of Foreign Persons' in SV Bakhin (ed), Urgent Problems of International Civil Procedure: Materials of an International Conference (Spb., 2003) 58-66.
}

sia and CEP Ukraine. Under the CAP Russia, arbitrazh courts consider cases with regard to economic disputes and other cases connected with the effectuation of entrepreneurial and other economic activity with the participation of foreign persons if:

(1) the defendant is situated or resides on the territory of the Russian Federation or property of the defendant is situated on the territory of the Russian Federation;

(2) the management organ, branch, or representation of a foreign person is situated on the territory of the Russian Federation;

(3) the dispute arose from a contract with regard to which performance should take place or did take place on the territory of the Russian Federation;

(4) the demand arose from the causing of harm to property by an action or other circumstance which occurred on the territory of the Russian Federation or when harm ensued on the territory of the Russian Federation;

(5) the dispute arose from unjust enrichment which occurred on the territory of the Russian Federation;

(6) the plaintiff with regard to the case concerning defense of business reputation is situated in the Russian Federation;

(7) the dispute arose from relations connected with the circulation of securities whose issuance occurred on the territory of the Russian Federation;

(8) the applicant in the case concerning the establishment of a fact having legal significance points to the existence of this fact on the territory of the Russian Federation;

(9) the dispute arose from relations connected with the State registration of names and other objects and rendering of services on the Internet on the territory of the Russian Federation;

(10) in other instances when there is a close connection of the contested legal relation and the territory of the Russian Federation (Article 247(1), CAP Russia) ${ }^{20}$.

\footnotetext{
20 See VA Musin, 'Certain Peculiarities of the Participation in an Arbitrazh Proceeding of Foreign Persons' (2004) Russian Yearbook of Civil and Arbitrazh Procedure, 20022003; AI Kharsontsev, Competence of Arbitrazh Courts with Regard to the Consideration of Cases with the Participation of Foreign Persons (Ekaterinburg, 2002).
} 
A case accepted by an arbitrazh court for its own consideration in compliance with the rules for international particular jurisdiction must be considered by it in substance even if in the course of the proceedings with regard to the case it becomes relegated to the competence of a foreign court in connection with a change of location or place of residence of the persons participating in the case or with other circumstances (Article 247(4), CAP Russia) ${ }^{21}$.

Ukrainian legislation contains a diametrically opposite approach to the jurisdiction of economic courts in Ukraine over disputes with the participation of subjects of economic management. This principal difference from the Russian approach is that the CEP Ukraine equates particular jurisdiction and systemic jurisdiction over cases with the participation of foreign enterprises and organizations and those involving Ukrainian enterprises and organizations by reference to the general provisions of the CEP Ukraine. There are, accordingly, no special provisions in the CEP Ukraine with regard to cases with the participation of foreign subjects of economic management so far as jurisdiction is concerned. Extrapolating from the general provisions of CEP Ukraine, one may say that economic courts in Ukraine have particular jurisdiction over cases with the participation of foreign subjects of economic management that are:

(1) disputes arising during the conclusion, change, dissolution, and performance of economic contracts, including those relating to the privatization of property, and other grounds except (a) disputes concerning the privatization of the State housing fund; (b) disputes arising when agreeing standards and technical conditions; (c) disputes concerning the establishment of prices for a product or goods or tariffs for services or the performance of work, provided that these prices and tariffs may not be established by agreement of

\footnotetext{
21 It should be noted that the Code of Civil Procedure of the Russian Federation contains analogous provisions (Article 402) regulating the competence of courts of ordinary jurisdiction with respect to civil-law disputes with the participation of foreign persons. See AI Muranov, 'Competence of Courts of Ordinary Jurisdiction to Consider Entrepreneurial Disputes with the Participation of Foreign Persons in Light of the New Code of Arbitrazh Procedure of the Russian Federation' (2002) 3 Moscow Journal of International Law.
}

the parties according to Ukrainian legislation; (d) disputes arising from public-law relations and relegated to the competence of the Constitutional Court of Ukraine or administrative courts; (e) other disputes whose resolution in accordance with laws of Ukraine and international treaties of Ukraine are relegated to the jurisdiction of other agencies;

(2) bankruptcy cases;

(3) cases filed by the Anti-Monopoly Committee of Ukraine and the Counting Chamber on matters within their competence;

(4) cases arising from corporate relations in disputes between an economic society and a participant, founder, or stockholder, including a participant who has withdrawn, and between participants, founders, or stockholders of economic societies connected with the creation, activity, management, and termination of activity of such a society, except for labor disputes;

(5) disputes relating to recording rights to securities;

(6) disputes arising from land relations in which subjects of economic activity participate, except for those within the jurisdiction of administrative courts (Article 12(1), CEP Ukraine).

An earlier redaction of the CEP Ukraine had contained special provisions regarding two categories of disputes with the participation of foreign enterprises and organizations, namely: (a) if the territory of Ukraine was the location of a branch, representation, or other solitary subdivision of a foreign enterprise or organization; (b) if a foreign enterprise or organization had immoveable property on the territory of Ukraine with respect to which there was a dispute. The present redaction of the CEP Ukraine excluded these provisions, which equated the procedural status of national and foreign subjects of economic management to an even greater extent.

The CAP Russia and CEP Ukraine contain principles for determining the exclusive systemic jurisdiction of their respective courts in international economic disputes which differ significantly. The CAP Russia relegates cases certain cases with the participation of foreign persons to the exclusive systemic jurisdiction of arbitrazh courts: 
(1) disputes with respect to property in the State ownership of the Russian Federation, including disputes connected with the privatization of State property and compulsory alienation of property for State needs;

(2) disputes whose subject-matter is immoveable property if such property is on the territory of the Russian Federation, or rights thereto;

(3) disputes connected with the registration or issuance of patents, registration and issuance of certificates for trademarks, industrial designs, utility models, and the registration of other rights to the results of intellectual activity which require the registration or issuance of a patent or certificate in the Russian Federation;

(4) disputes on deeming invalid entries in State registers (or cadastres) made by a competent agency of the Russian Federation keeping such register (or cadastre);

(5) disputes connected with the founding, liquidation, or registration on the territory of the Russian Federation of juridical persons and individual entrepreneurs, and also contesting decisions of the organs of these juridical persons (Article 248(1), CAP Russia).

In addition to the foregoing, the CAP Russia mentioned another principle extending the jurisdiction of arbitrazh courts to cases with the participation of foreign persons arising from administrative and other publiclaw relations (Article 248(2)).

Ukrainian legislation here too applies the principle of national regime and equates foreign and Ukrainian subjects of economic management, but with respect to a broader range of grounds for such particular jurisdiction in comparison with Russian law. There are relegated to the particular jurisdiction of Ukrainian economic courts:

(1) disputes which arise from a contract of carriage in which one of the defendants is a transport agency, in which event the cases are considered by the economic court at the location of the transport agency;

(2) disputes concerning arrest of the ship which is executed as a security of the maritime claim. Such cases are considered by an economic court at the location of the sea port of Ukraine in which the ship is situated, or of the sea port where the ship is registered;

(3) disputes concerning the right of ownership to property or to demanding and obtaining property from another's illegal possession or eliminating obstacles to the use of property, these cases also being considered by the economic court at the location of the property;

(4) disputes concerning a violation of intellectual property rights, these cases being considered at the place where the violation was committed;

(5) disputes in which the defendant is a higher or central agency of executive power, the National Bank of Ukraine, the Chamber of Auditors, the Supreme Rada of the Autonomous Republic of Crimea, the Council of Ministers of the Autonomous Republic of Crimea, regional, Kiev, and Sevastopol city councils or regional, Kiev, and Sevastopol city State administrations, as well as cases whose materials contain State secrets. These cases are all considered by the Economic Court of the City of Kiev;

(6) disputes between an economic society and participant, founder, or stockholder thereof, including a participant who has withdrawn, and also between participants, founders, or stockholders of an economic society connected with the creation, activity, management, or termination of the activity of this society. Such cases are considered by an economic court at the location of the economic society pursuant to the Unified State Register of Juridical Persons and Natural Person-Entrepreneurs;

(7) disputes relating to the recording of rights to securities, these cases being considered by an economic court at the location of the issuer;

(8) disputes arising from land relations in which subjects of economic activity participate. These cases are considered by the economic court at the location of the objects of land relations or the principal part thereof (Article 16(1)-(8), CEP Ukraine).

Unlike Russian legislation, the CEP Ukraine specially included in its enumeration of disputes within the exclusive systemic jurisdiction of economic courts those enumerated in subpoints (6) to (8) in the 
preceding paragraph. In this context Ukrainian legislation appears to be more progressive than the CAP Russia. This has implications for the conclusion of a choice of forum agreement between parties in dispute or, for that matter, legal assistance treaties between Russia and Ukraine.

The rules concerning the contractual jurisdiction in Russia are to be found in Article 249 of the CAP Russia. If the parties, one of which is a foreign person, have concluded an agreement in which they determined that an arbitrazh court in the Russian Federation possesses competence to consider a dispute which arose or might arise connected with the effectuation by them of entrepreneurial or other economic activity, the arbitrazh court in the Russian Federation will possess exclusive competence for the consideration of this dispute on condition that such an agreement does not change the exclusive competence of a foreign court. The agreement concerning the choice of jurisdiction must be concluded in written form ${ }^{22}$. A choice of forum agreement thus has in view an arrangement between the parties in dispute or a potential plaintiff and defendant to transfer a dispute for settlement to the court of a particular State. Such an agreement acts as a legal form of realizing the norms concerning contractual systemic jurisdiction contained in municipal law.

The formulation of the heading of Article 249 of the CAP Russia is not wholly satisfactory. It refers in substance to the form of a choice of forum agreement, whereas what it should actually refer to is a choice of forum rather than the agreement which is merely the legal form of the expression of choice. It would be more accurate to entitle Article 249 "Contractual Systemic Jurisdiction of Cases with the Participation of Foreign Persons", a formulation that would, first, enable the types of systemic jurisdiction to be distinguished - general (Article

\footnotetext{
22 On the legal nature, form, and validity of such agreements determining systemic jurisdiction, see YuE Monastyrsky, 'Basic Peculiarities of Prorogation Agreements in the Russian Federation' (2002) 2 Moscow Journal of International Law 174-185; see also SA Dergachev, 'Peculiarities of Choice of Forum Agreements Establishing National Jurisdiction with the Participation of Foreign Element' (2010) 6 Public and Private International Law.
}

247, CAP Russia; Article 12, CEP Ukraine), exclusive (Article 248 (CAP Russia; Article 16, CEP Ukraine), and contractual (Article 249, CAP Russia). Second, this formulation would help to distinguish between a choice of forum agreement as a mean of determining systemic jurisdiction in the form of realizing contractual systemic jurisdiction from the concept of systemic jurisdiction itself as a complex of rules for establishing the competence of a particular State court.

Regrettably, the CEP Ukraine does not mention contractual systemic jurisdiction at all, which measured by modern standards of international procedure law must be regarded as a serious shortcoming. In our view it should be stressed that a choice of forum agreement may change only the rules for determining general systemic jurisdiction, but never exclusive systemic jurisdiction. To undertake the last would risk the clause being deemed to be invalid. Contractual choice of forum clauses are a form, in CIS jurisdictions, of changing general systemic jurisdiction by agreement between the parties in dispute or potential parties in dispute ${ }^{23}$.

A principal rule regulating jurisdictional issues with a foreign element is the location of the defendant or respondent (juridical or natural person). This rule is reflected in Russian and Ukrainian procedural legislation (Article 247(1)(1), CAP Russia; Article 15(1), CEP Ukraine). The CAP Russia, however, contains an unusual innovation as a criterion for establishing the jurisdiction of a Russian arbitrazh court - the existence of a close link between the legal relation in dispute and the territory of Russia (Article 247(1)(10), CAP Russia). No other country known to us has such a criterion in procedural legislation. The category of a "close link" is, of course, a conflicts link only with respect to the choice of applicable material law but does not operate as such when choosing a forum. The reason doubt-

\footnotetext{
For an analysis of the categories of general and exclusive systemic jurisdiction, see NA Shebanova, 'Procedural Peculiarities of the Consideration of Cases with the Participation of Foreign Persons in Arbitrazh Courts of the Russian Federation' in MM Boguslavsky and AG Svetlanov (eds), Private International Law: Modern Practice: Collection of Articles (Moscow 2000) 290-299.
} 
less is that factual circumstances underlie the norms enabling the jurisdictional organ to be chosen which unequivocally link the Russian arbitrazh court and the dispute which it is proposed to refer for its consideration (for example, the management organ, branch, or representation of a foreign person is situated on the territory of the Russian Federation Article 247(1)(2), CAP Russia). The category of a "close link" does not enable one to unequivocally select a Russian arbitrazh court as a jurisdictional organ for the settlement of a dispute since the link of the legal relation in dispute with the territory of Russia itself requires an agreed choice. The innovation introduced in the CAP Russia can hardly be considered to be convincing.

The principles for determining the jurisdiction of courts contained in Russian and Ukrainian legislation are similar to those contained in the 1993 Minsk Convention on Legal Assistance and Legal Relations in Civil, Family, and Criminal Matters (hereinafter: the Minsk Convention), as amended by the Moscow Protocol of $1997^{24}$. The Minsk Convention is a regional multilateral international treaty which establishes the basic principles for citizens and juridical persons from one Contracting Party to have recourse to the courts on the territory of another Contracting Party. The principle of national regime (Article 1) and the principle of delimitation of the territorial systemic jurisdiction on the basis of place of residence or location of the defendant (Article 20) are the principal Convention provisions important for determining international systemic jurisdiction.

Article 1 of the Minsk Convention provides that citizens of each of the Contracting Parties, as well as persons residing on the territory thereof, enjoy on the territories of all other Contracting Parties the same legal protection as own citizens of the particular Contracting Party. Thus, the citizens of each Contracting Party, and other persons residing on

\footnotetext{
24 Бюллетень международных договоров, (1995) nо. 2; no. 4 (2008). The Minsk Convention entered into force on 19 May 1994. For Russia it entered into force on 10 December 1994 and for Ukraine on 14 April 1995. The Moscow Protocol entered into force on 17 September 1999, and for Russia on 9 January 2001, and for Ukraine on 17 September 1999.
}

the territory thereof, have the right to freely and without obstruction apply to the courts of other Contracting Parties within whose competence civil and family cases are (hereinafter: justice institutions), may appear in them, file petitions and suits, and perform other procedural actions on the same conditions as citizens of that particular Contracting Party. The Convention provisions also apply to juridical persons created in accordance with legislation of the Contracting Parties.

Article 20 of the Minsk Convention stipulates that suits against persons having a place of residence of the territory of one Contracting Party are to be filed irrespective of their citizenship in the courts of that Contracting Party, and suits against juridical persons are filed in the courts of the Contracting Party on whose territory the management organ of the juridical person or a representation of branch thereof are situated. If several defendants take part in a case who have a place of residence or location on the territories of different Contracting parties, the dispute is considered at the place of residence or location of any defendant, at the choice of the plaintiff. The courts of the Contracting Parties are competent also in instances when on the territory thereof:

(1) trade, industrial or other economic activity of an enterprise or a branch of the defendant is carried out;

(2) obligations from a contract which is the subject-matter of a dispute is performed or should be performed in part or entirely;

(3) the plaintiff with regard to a suit concerning the defense of honor, dignity, and business reputation has a permanent place of residence or location.

Under the Minsk Convention, courts at the location of property have exclusive jurisdiction with regard to suits concerning the right of ownership or other rights to a thing to immoveable property. Suits against carriers arising from contracts of carriage of cargo, passengers, and baggage are filed at the location of the management of a transport organization against whom a claim was filed in the established procedure. These last two grounds are examples of the Convention establishing the exclusive jurisdiction of a court of a par- 
ticular Contracting Party which may not be changed by arrangement of the parties and, accordingly, may not be the subject-matter of a choice of forum agreement. If there were such a choice of forum agreement, upon the application of the defendant the court would terminate the proceedings in the case.

The Minsk Convention also regulates contractual systemic jurisdiction. According to Article 21 of the Convention, courts of the Contracting Parties may consider cases also when there is a written agreement of the parties to refer a dispute to those courts. The exclusive systemic jurisdiction stipulated by Article 20 of the Minsk Convention and by other rules as well as from the internal legislation of the respective Contracting Party cannot be changed by the agreement of the parties of the dispute. If there were such a choice of forum agreement, upon the application of the defendant the court shall terminate the proceedings in the case.

The Kiev Agreement on the Procedure for the Settlement of Disputes Connected with the Effectuation of Economic Activity (hereinafter: the Kiev Agreement) also contains provisions regulating the establishment of systemic jurisdiction in cases with the participation of foreign persons ${ }^{25}$. The Kiev Agreement regulates, inter alia, the consideration of cases arising from contractual and other civil-law relations between economic subjects (Article 1). To this end, the Kiev Agreement contains norms concerning general, exclusive, and contractual systemic jurisdiction. A court of a Contracting Party is competent to consider a dispute with regard to cases in which foreign persons participate where:

(1) the defendant has a permanent place of residence or location on the day the suit was filed;

(2) trade or industrial or other economic activity of an enterprise or branch of the defendant is carried out;

(3) an obligation from a contract which is the subject-matter of the dispute was per-

\footnotetext{
25 Информационный вестник Совета глав государств и Совета глав правительств СНГ «Содружество» (1992), no. 4. The Kiev Agreement entered into force on 19 December 1992, including for Russia and Ukraine on that date.
}

formed or should have been performed in full or in pat;

(4) an action or other obligation serving as grounds for a demand concerning compensation of harm occurred;

(5) the plaintiff in a suit concerning the protection of business reputation has a permanent place of residence or location;

(6) a supplier, independent-work contractor, or person rendering a service or performing work as a contracting party is situated, and the dispute concerns the conclusion, change, or dissolution of contracts (Article 4(1), Kiev Agreement).

With respect to the exclusive jurisdiction, the Kiev Agreement provides that suits filed by subjects of economic management concerning the right of ownership to immoveable property are to be considered solely by the court of the Contracting Party on whose territory the property is situated (Article 4(3), Kiev Agreement). Similarly, cases to deem invalid in full or in part, acts not having a normative character of State and other agencies, or suits concerning compensation of losses caused to economic subjects by such acts or losses which arose as a consequence of the improper execution by the said agencies of their duties with respect to economic subjects, are considered solely by a court at the location of the said agency (Article 4(4), Kiev Agreement). A similar rule is applicable to a counter suit or a demand for set-off arising from the same legal relation as the basic suit - these are subject to consideration in that court which considers the basic suit (Article 4(5), Kiev Agreement).

Contractual systemic jurisdiction determined by the Kiev Agreement assumes that the courts of the Contracting Parties consider cases if there is a written agreement of the parties to refer a dispute to this court. When there is such an agreement, the court of another Contracting Party terminates the proceedings in the case upon the application of the defendant provided that such an application is made before the decision is adopted in the case (Article 4(2), Kiev Agreement). A choice of forum agreement may not change the exclusive systemic jurisdiction of a court 
competent to consider a case in accordance with Article 4(3)-(4), Kiev Agreement. The Kiev Agreement is, therefore, for its Contracting Parties the principal international treaty of a special character regulating systemic jurisdiction with regard to economic disputes. Georgia and Moldova are not parties to the Kiev Agreement, which means that the Minsk Convention applies to determine systemic jurisdiction with regard to economic disputes with the participation of juridical persons and citizens of those States - the Minsk Convention having more parties than the Kiev Agreement does.

There are several bilateral treaties either of Russia, or of Ukraine that address legal assistance in civil, family, and criminal cases in which issues of systemic jurisdiction with regard to economic disputes are addressed. As a rule, the court of the Contracting Party competent to consider a dispute is that court at the place of residence on the territory of that State of the natural person or the location of the management organ, representation, or branch of a juridical person. The question naturally arises as to the correlation of the multilateral and bilateral treaties to which Russia and Ukraine are parties with the norms of municipal legislation set out in the CAP Russia and CEP Ukraine.

Guided by the general principles of public and private international law, we would suggest the following. When disputes fall within the purview of bilateral treaties of Russia and Ukraine on legal assistance, those treaties should be applied to determined systemic jurisdiction with respect to disputes with the participation of foreign persons from those two States on the principle of lex specialis. Systemic jurisdiction with regard to economic disputes with the participation of Russian and Ukrainian citizens between themselves, or with juridical persons and citizens of other CIS countries, should be determined on the basis of the Kiev Agreement or, if citizens of Georgia and/or Moldova are involved, the Minsk Convention. The norms of the CAP Russia or the CEP Ukraine would apply when determining systemic jurisdiction if a participant of a foreign economic transaction emanates from a State with which
Russia and Ukraine have no bilateral or multilateral treaties containing norms on establishment the jurisdiction of courts with regard to economic disputes with the participation of foreign persons.

\section{2) Recognition and Enforcement of Foreign Judgments on the Territory of Russia and Ukraine}

The ultimate issue for international civil procedure is whether a judgment rendered in one State can be recognized and enforced in another, because it is this procedural stage which represents the final disposition of the legal relations in dispute between parties in the form of the material satisfaction of the plaintiff's demands. The difficulty is that a judgment, being an act of public power of one State adopted within the limits of its jurisdiction, must be recognized and enforced on the territory of another State to which the public power of the first State does not extend. The generally-recognized international legal principles of territorial integrity and the sovereign equality of States mean that a foreign judgment will be recognized and enforced on the territory of a State only when either the legislation of that State so permits, or an international treaty of that State so permits, or both. Russian and Ukrainian law offer both alternatives ${ }^{26}$.

Chapter 31 of the CAP Russia is titled as "Proceeding with Regard to Cases Concerning Recognition and Enforcement of Foreign Judgments and Foreign Arbitral Awards".

\footnotetext{
26 This is a subject of tremendous theoretical and practical interest in Russia and Kazakhstan, reflecting the greater involvement of both countries in foreign economic and investment relations. See AI Muranov, Enforcement of Foreign Judgments and Arbitral Awards: Competence of Russian Courts (Moscow, 2002); AI Muranov, International Treaty and Reciprocity as Grounds for Enforcement of Foreign Judgments in Russia (Moscow, 2003); DV Livtinsky, Recognition of Foreign Judgments in Civil Cases (Comparative Legal Analysis of French Legislation, Judicial Practice, and Legal Doctrine) (Spb., 2005); RV Zaitsev, Recognition and Enforcement in Russia of Foreign Judicial Acts (Moscow, 2007). A number of works appeared in Imperial Russia on the subject. See P Markov, 'On the Enforcement of Decisions of Judicial Instances of Foreign States' (1864) XXII Journal of Ministry of Justice 25-46, 211-224; IE Engelman, 'On the Enforcement of Foreign Judgments in Russia' (1884) 1 Journal of Civil and Criminal Law 75-121.
} 
The CAP Russia provides (Article 241(1)) that judgments of foreign States adopted by them with regard to disputes and other cases arising when effectuating entrepreneurial and other economic activity (foreign courts) shall be recognized and enforced in the Russian Federation by arbitrazh courts if recognition and enforcement of such judgments is provided for by an international treaty of the Russian Federation and a federal law ${ }^{27}$.

Ukraine regulates this issue in Section VIII "On the Recognition and Enforcement of Judgments of Foreign Courts in Ukraine" in the Code of Civil Procedure of Ukraine (hereinafter: CCP Ukraine) of 18 March 2004, as amended 6 November $2012^{28}$. Article 390(1)-(2) of the CCP Ukraine provides that judgments of foreign courts (courts of foreign States, other agencies of foreign States within whose competence is the consideration of civil and economic disputes; foreign or international arbitral tribunals) shall be recognized and enforced in Ukraine if the recognition and enforcement thereof is provided for by international treaties, consent to the bindingness of which has been given by the Supreme Rada of Ukraine or on the basis of the principle of reciprocity.

CCP Ukraine precisely singles out the principle of reciprocity as an autonomous ground for the recognition and enforcement of foreign judgments on the territory of Ukraine. A formal logical analysis of Russian legislation hardly enables one to come to an analogous conclusion. The possibility of the recognition and enforcement of foreign judgments on the basis of a federal law means the introduction of a new ground for such recognition and enforcement - the principle of reciprocity, which shall be consolidated in individual federal laws ${ }^{29}$. There is only one

\footnotetext{
27 See VA Kanashevsky, 'On the Grounds for Recognition and Enforcement of Foreign Judgments According to Russian and Foreign Law' (2006) 4 Journal of Private International Law.

28 Ведомости Верховной Рады Украины (2004), no. 4042, item 492; Официальный вестник Украины (2012), по. 91/13, item 3668.

29 See DV Litvinsky, 'Reciprocity in the Domain of Recognition and Enforcement of Judgments of Foreign States' (2002) 2-3 Journal of Private International Law; VO Abolonin, 'Concept of Reciprocity in International Civil Procedure'
}

example of such law - the Federal Law on Insolvency (Bankruptcy) of 26 October 2002, as amended 30 December $2012^{30}$.

Article 1(6) of this law says that the judgments of foreign states rendered in cases of insolvency (bankruptcy) shall be recognized on the territory of Russia in accordance with the international treaties of Russia. In case of an absence of such treaties the judgments of foreign states rendered in cases of insolvency (bankruptcy) shall be recognized on the territory of Russia in accordance with principle of reciprocity if otherwise is not provided by the federal law. In above-mentioned rule of federal law we are talking only about the recognition of foreign judgment on the ground of reciprocity, but not about its enforcement. Moreover, the principle of reciprocity serves as the basis for the recognition and enforcement of only those foreign judgments which have been rendered with regard to disputes arising from insolvency (bankruptcy) proceedings. In above-mentioned rule of the federal law we are talking only about the recognition of foreign judgment on the ground of reciprocity, but not about its enforcement. Thus, it must be stresses that in Russia, unlike Kazakhstan, the principle of reciprocity serves as the basis for the recognition and enforcement of only those foreign judgments which have been rendered with regard to disputes arising from insolvency (bankruptcy) proceedings.

The procedure for recognition and enforcement of a foreign judgment is as follows. An application or petition to recognize

(2004) 3 Arbitrazh and Civil Procedure; K Branovitsky, 'Principle of Reciprocity in International Civil Procedure' (2005) 8 Arbitrazh and Civil Procedure; DV Litvinsky, 'Principles of "Reciprocity" and "Right to Trial" in Domain of Exequatur for Enforcement in Russia of Foreign Judgments: Decree of the Federal Arbitrazh Court of Moscow District of 2 March 2006' (2006) 4 International Commercial Arbitration; DV Litvinsky, "Never Refuse to Enforce": Once More on the Question of the Possibility of Enforcing Judgments of Foreign Courts on the Territory of the Russian Federation in the Absence of an International Treaty' (2006) 4-5 Herald of Supreme Arbitrazh Court of the Russian Federation; VYu Knutova, 'Enforcement of Foreign Judgment in the Russian Federation in the Absence of an International Treaty on Legal Assistance' (2010) 4 Arbitrazh Practice; P Martinez-Fraga, The New Role of Comity in Private Procedural International Law (Global Law Collection Series, 2007).

30 C3 РФ (2002), no. 43, item 4190; (2012), no. 53, part 1, item 7619 . 
and enforce a judgment of a foreign court is filed by a party to the dispute in whose favor the judgment was rendered in an arbitrazh court of a subject of the Russian Federation or in a court of ordinary jurisdiction of Ukraine at the location or place of residence (or presence) of the debtor or, if the location or place of residence (or presence) of the debtor is unknown, at the location of property of the debtor (Article 242 (1)-(2), CAP Russia; Article 392(1)-(2), CCP Ukraine). The said application is filed in written form and must be signed by the recovering party or a representative thereof.

Russian legislation adds that this application also may be filed by means of completing a form on the official website of the arbitrazh court (Article 242(2), CAP Russia). Ukrainian legislation also provides for another means of filing a petition to recognize and enforce a foreign judgment: if an international treaty, consent to the bindingness of which was given by the Supreme Rada of Ukraine, provides for the filing of such a petition through agencies of State power of Ukraine, the court will accept a petition for consideration received by this means (Article 393(2), CCP Ukraine).

There must be appended to the application or petition to recognize and enforce the foreign judgment:

(1) copy duly certified of a foreign judgment for whose recognition and enforcement the recoverer petitions;

(2) document duly certified and confirming the entry of a foreign judgment into legal force unless this is specified in the text of the judgment itself;

(3) document duly certified and confirming that the debtor was timely and duly notified about the proceedings in a foreign court, for the recognition and enforcement of whose judgment the recoverer petitions;

(4) power of attorney or other document certifying duly and confirming the powers of the person who signed the application to the arbitrazh court;

(5) document confirming the sending to the debtor of a copy of the application concerning recognition and enforcement of a foreign judgment (Article 242(3)(5), CAP Russia), or a document determining in what part or from what time a foreign judgment is subject to enforcement if it has been enforced previously (Article 394(3)(6), CCP Ukraine);

(6) duly certified translation of the documents specified in points (1) to (5) of the present paragraph into the Russian language (Article 242(3), CAP Russia) or Ukrainian language (Article 394(3)(6), CCP Ukraine).

The application or petition to recognize and enforce a foreign judgment is considered in a judicial session by one judge sitting alone within a period not exceeding three months from the day of receipt at an arbitrazh court in the Russian Federation. In Ukraine, the said consideration must happen within a period not exceeding one month from the day of notification of the debtor about the petition received by a court of ordinary jurisdiction in Ukraine. The Ukrainian court must notify the debtor about receiving the petition within five days from the moment of receipt ${ }^{31}$.

The arbitrazh court in Russia or the court of ordinary jurisdiction in Ukraine will render a ruling to authorize the enforcement of a foreign judgment on the territory of Russia or Ukraine respectively after having considered the application or petition. The ruling of a Russian arbitrazh court may be appealed to an arbitrazh court of cassational instance within a month from the day of the rendering of the ruling (Article 245(3), CAP Russia). The ruling of a court of general jurisdiction of Ukraine authorizing enforcement of a foreign judgment may be appealed to a court of appellate or cassational instance (Article 397, CCP Ukraine).

A foreign judgment is enforced in Russia and Ukraine on the basis of a writ of execution issued respectively by a Russian arbitrazh court or a Ukrainian court of ordinary jurisdiction, each of which will have rendered a ruling to recognize and enforce the foreign court decision by way of what is called an "execution proceeding" (Ar-

\footnotetext{
31 See SV Tarnopolskaya, 'Systemic Jurisdiction over Cases concerning Enforcement of Arbitral Awards and Cases concerning Recognition and Enforcement of Foreign Judgments and Arbitral Awards' (2008) 1 Law.
} 
ticle 246(1), CAP Russia; Article 398, CCP Ukraine). In each country the period of limitations for submitting a foreign judgment for execution is three years from the day of the entry thereof into legal force (Article 246(2), CAP Russia; Article 391, CCP Ukraine) ${ }^{32}$.

The Russian and Ukrainian codes contain a virtually identical list of grounds for a refusal to recognize and enforce (Article 244, CAP Russia; Article 396, CCP Ukraine). A refusal is permitted in the following instances, the list of which is exhaustive in Russian legislation and exemplary in Ukrainian legislation ${ }^{33}$ :

(1) the judgment according to the law of the State on whose territory it was adopted has not entered into legal force;

(2) the party against whom the judgment was adopted was not timely and duly notified about the time and place of consideration of the case or for other reasons could not submit its explanations to the court;

(3) consideration of the case in accordance with an international treaty of the Russian Federation or Ukraine or legislation of Russia or Ukraine is relegated to the exclusive competence of a court in the Russian Federation or a court of ordinary jurisdiction of Ukraine;

(4) there is a judgment of a court in the Russian Federation or Ukraine which has entered into legal force adopted with regard to a dispute between the same persons, the same subject-matter, and on the same grounds;

(5) a case with regard to a dispute between the same persons, on the same subject-matter, and on the same grounds is under consideration of a court in the Russian Federation or Ukraine, the proceeding with regard to which was instituted before the instituting of the proceeding with regard to the case in a foreign court, or the court in the Russian Federation or Ukraine was the first to accept an application for its own proceed-

\footnotetext{
32 See TN Neshataeva, 'On the Recognition and Enforcement of Foreign Judgments and Arbitral Awards' (2004) 11 Arbitrazh Practice; DV Konev, 'Individual Issues of the Recognition and Enforcement of Foreign Judgments' (2007) 1-2 Arbitrazh and Civil Procedure; IuA Svirin, 'Theoretical and Legal Foundations of Enforcement of Foreign Judgments in the Russian Federation' (2008) 2 Advertising and Law.

33 See EV Vinter, 'Grounds for Refusal to Recognize and Enforce Foreign Judgments' (2006) 4 Moscow Journal of International Law.
}

ing with regard to the dispute between the same persons, on the same subject-matter, and on the same grounds;

(6) the period of limitations has expired for enforcing the judgment of a foreign court and this period is not restored by a court;

(7) enforcement of a judgment of a foreign court would be contrary to the public policy of the Russian Federation or would threaten the interests of Ukraine ${ }^{34}$;

(8) the subject-matter of the dispute according to Ukrainian legislation cannot be the subject-matter of a judicial examination.

Procedural practice on consideration of cases in relation to recognition and enforcement of foreign judgments was analyzed in Survey of Practice of Consideration by Arbitrazh Courts of Cases Concerning Recognition and Enforcement of Foreign Judgments, Contesting of Arbitral Awards, and Issuance of Writs of Execution for Enforcement of Arbitral Awards prepared by the Higher Arbitrazh Court of the Russian Federation (No. 96 as of 22 December 2005) $)^{35}$.

The most important findings of the higher court instance can be presented as follows:

1. Arbitrazh court upon consideration of the claim on recognition and enforcement of the foreign judgment is not entitled to revise the subject-matter of the foreign judgment (item 4);

2. Arbitrazh court shall satisfy the claim on recognition and enforcement of the foreign judgment upon existence of proof evidencing the fact that there is a judgment of the Russian court that has come into legal force on other dispute between the same parties (item 5);

3. Arbitrazh court upon consideration of the dispute about summoning the party against which the judgment was rendered shall inspect if the party had a possibility to defend in connection with the absence of real and timely notification about the time and place of the proceedings (item 6);

\footnotetext{
34 See BR Karabelnikov, 'Public Policy Clause in Recent Practice of Russian and Foreign Courts' (2006) 1 International Commercial Arbitration; SV Krokhalev, Category of Public Policy in International Civil Procedure (SPb., 2006).

35 Вестник Высшего арбитражного суда РФ (2006), nо. 3.
} 
4. Arbitrazh court makes a ruling on recognition and enforcement of the foreign judgment provided that such a judgment has come into legal force in accordance with the legislation of the state where it has been rendered (item 7);

5. Arbitrazh court has the right to refuse to recognize and enforce the foreign judgment provided that it has found that this judgment is rendered in the dispute falling withing the exclusive jurisdiction of the Russian arbitrazh courts (item 8);

6. Arbitrazh court makes a ruling on satisfaction of the claim on obligatory execution of the foreign judgment provided that the way of execution prescribed in the judgment shall not conflict with the public policy of the Russian Federation (item 31).

Unlike Russian legislation, CCP Ukraine contains an autonomous institute of recognizing foreign judgments which are not subject to enforcement. Section VIII, Chapter 2 of CCP Ukraine is devoted to this issue. A foreign judgment not subject to enforcement is recognized in Ukraine if the recognition thereof is provided for by an international treaty, consent to the bindingness of which was given by the Supreme Rada of Ukraine, or such recognition is given on the basis of reciprocity (Article 399, CCP Ukraine). A petition to recognize a foreign judgment not subject to enforcement is filed by the interested person in a court of general jurisdiction of Ukraine in the procedure established by Articles 392 to 394 of CCP Ukraine, which regulate the procedure for petitioning to enforce a foreign judgment. The following documents must be appended to the petition to recognize a foreign judgment:

(1) a duly certified copy of a foreign judgment whose recognition is being sought;

(2) an official document that a foreign judgment has entered into legal force unless this is indicated in the judgment itself;

(3) a duly certified translation of the aforesaid documents into the Ukrainian language or into the language provided by the international treaty, consent to the bindingness of which was given by the Supreme Rada of Ukraine (Article 400(1)-(2), CCP Ukraine).
The Ukrainian court within a five-day period notifies the interested party in writing about the petition to recognize a foreign judgment not subject to enforcement and suggests that any objections against this petition be filed within a month. After objections of the interested person have been submitted in written form or if he declines to file objections, or when a month has elapsed from the moment of notification of the interested person that the court has received the petition and no objections have been received, the judge renders a ruling which designates a time and place for a judicial examination, which must be communicated to the interested persons not less than ten days before the judicial examination (Article 401(1), CCP Ukraine). The petition to recognize a foreign judgment not subject to enforcement is considered by the judge sitting alone in an open judicial session (Article 401(4), CCP Ukraine).

The failure of interested persons or their representatives to appear without justifiable reasons at the judicial session and who were duly notified by the court by way of a summons is not an obstacle to consideration of the petition unless any one of the interested persons requested that the judicial session shall be postponed. The court renders a ruling to recognize a foreign judgment in Ukraine or to refuse to satisfy the petition. Recognition of a foreign judgment not subject to enforcement may be refused in Ukraine on the grounds established by Article 396 of CCP Ukraine, which are in fact those set out in Article 401(5)-(7) of the said Code. The ruling of the Ukrainian court to either recognize or not to recognize a foreign judgment may be appealed by way of appellate or cassational proceedings (Article 401(9), CCP Ukraine).

The procedure for the recognition and enforcement of foreign judgments also is regulated by treaties entered into by Russia and Ukraine $^{36}$. The Minsk Convention, in particular, contains Section III devoted to "Recognition and Enforcement of Decisions" ${ }^{" 37}$. In the Minsk

\footnotetext{
36 See AA Matveev, 'Russia and International Treaties on Recognition and Enforcement of Foreign Judgments' (2004) 2 Moscow Journal of International Law.

37 See AA Egorov, 'Recognition and Enforcement of Judgments of Member Countries of the CIS Minsk Convention' (1998) 12 Legislation and Economics.
} 
Convention the term "decision" encompasses the decisions of justice institutions relating to civil and family cases, including judgments of the courts, amicable agreements confirmed by the court with regard to such cases and notarial acts with respect to monetary obligations. Decisions rendered by justice institutions of each of the Contracting Parties that have entered into legal force not by their nature requiring enforcement are recognized on the territories of the other Contracting Parties without a special proceeding provided that:

(1) the justice institution being requested has not previously rendered a decision with regard to this case which has entered into legal force;

(2) the case under the Minsk Convention or in instances not provided for by it, under legislation of the Contracting Party on whose territory the decision is to be recognized, is not within the exclusive competence of justice institutions of that Contracting Party (Article 52, Minsk Convention).

A petition to enforce a decision is filed in the competent court of the Contracting Party where the decision is subject to being enforced. It may be filed also in the court which rendered the decision in the case at first instance. This court then refers the petition to the court competent to render a decision on the petition. There must be attached to the petition:

(1) the decision or a certified copy thereof, and also an official document that the decision has entered into legal force and is subject to enforcement, or that it is subject to enforcement before entry into legal force unless this follows from the decision itself;

(2) a document from which it follows that the party against whom the decision was rendered and who did not take part in the proceeding was duly and timely summoned to court, and in the event of the lack of procedural dispositive legal capacity, was duly represented;

(3) a document confirming the partial enforcement of the decision at the moment of referral thereof;

(4) a document confirming the agreement of the parties with regard to cases based on contractual systemic jurisdiction.

The petition to authorize enforcement and the appended documents must be ac- companied by a certified translation into the language of the Contracting Party being requested or into the Russian language (Article 53, Minsk Convention). These petitions are then considered by the courts of the Contracting Party on whose territory the enforcement is sought. The court considering the petition is to confine itself to determining whether the conditions provided for by the Minsk Convention have been complied with. If they have, the court renders a decision to enforce. The procedure for enforcement is determined by legislation of the Contracting Party on whose territory the enforcement is sought (Article 54, Minsk Convention) ${ }^{38}$.

Enforcement may be refused if:

(1) in accordance with legislation of the Contracting Party on whose territory the decision was rendered it has not entered into legal force and is not subject to enforcement, except for instances when the decision is subject to enforcement prior to entry into force;

(2) the defendant did not take part in the proceeding because neither he nor anyone else duly empowered was properly and timely summoned to the court;

(3) a decision was rendered and has entered into legal force with regard to a case between the same parties, same subject-matter, and same grounds on the territory of a Contracting Party where the decision is to be recognized and enforced, or there is a recognized decision of a court of a third State, or a proceeding with regard to this case was instituted by a judicial institution of this Contracting Party previously;

(4) under the Minsk Convention or in instances not provided by it, under the legislation of the Contracting Party on whose territory the decision was recognized and enforced, the case is within the exclusive competence of an institution thereof;

(5) the document confirming an agreement with regard to a case of contractual systemic jurisdiction is absent;

(6) the period of limitations for enforcement provided by legislation of the Contracting Party whose court is enforcing the decision has

\footnotetext{
In practice this means that if the enforcement is to be in Russia or in Ukraine, the provisions of Chapter 31 of the CAP Russia or Section VIII of the CCP Ukraine will be applied.
} 
lapsed (Article 55, Minsk Convention).

The other regional international treaty of relevance to the recognition and enforcement of foreign judgments is the Kiev Agreement. Pursuant to that Agreement, the Member States assumed an obligation to reciprocally recognize and enforce the judgments of competent courts which have entered into legal force (Article 7). The precise formulation of the Kiev Agreement is that judgments rendered by the competent courts of one Member State are subject to recognition on the territory of other CIS Member States. This means that the Kiev Agreement does not make provision for a judicial proceeding to authorize enforcement. Accordingly, a petition to enforce the judgment by an interested party is not a petition to authorize enforcement.

Therefore, among the documents to be appended to the petition (duly certified copy of the judgment whose enforcement is being sought; official document that the judgment has entered into legal force unless this is evident from the text of the judgment itself; evidence of notification of the other party about the proceeding) is a document of enforcement (Article $8)^{39}$. The Kiev Agreement merely provides for a judicial proceeding with regard to a refusal to enforce a judgment at the request of the party against whom it is directed and consolidates the list of evidence which must be presented to the competent court at the place where enforcement is being sought. Among such evidence to be presented is:

(1) that a court of the requested CIS State has previously rendered a judgment that has

\footnotetext{
39 According to the Information Letter of the Presidium of the Supreme Arbitrazh Court of the Russian Federation, No. 96 (point 1), "Survey of Practice of Consideration by Arbitrazh Courts of Cases Concerning Recognition and Enforcement of Foreign Judgments, Contesting of Arbitral Awards, and Issuance of Writs of Execution for Enforcement of Arbitral Awards", of 22 December 2005, when a Russian arbitrazh court considers an application to enforce a judgment of a court rendered on the territory of a party to the Kiev Agreement, in the absence of the document of enforcement mentioned in Article 8 of the Kiev Agreement, the court of first instance in Russia must leave the application without movement and establish a period during which the petitioner is to submit the document of enforcement. In the event of the failure to submit the document within the established period, the court must return the application to the petitioner on the basis of CAP Russia (Article 128(4)).
}

entered into legal force in a case between the same parties, the same subject-matter, and on the same grounds;

(2) there is a judgment of a competent court of a third CIS country whose judgment has been recognized, or a court of a State which is not a member of the CIS, with regard to a dispute between the same parties, on the same subject-matter, and on the same grounds;

(3) the dispute was settled by a court lacking competence;

(4) the other party was not notified about the proceeding;

(5) the three-year period of limitations for enforcement of the judgment was lapsed (Article 9, Kiev Agreement).

The Kiev Agreement accordingly does not require a court proceeding for the recognition and enforcement of a foreign judgment rendered by a competent court of a party to the Agreement, which means the recognition and enforcement thereof without a judicial proceeding. In this context the petition to enforce the judgment is the equivalent to an application to institute an execution proceeding. It should be noted that the Kiev Agreement makes provision for the possibility to execute judgments not only by court bailiffs, but also by other agencies designed by a court or by legislation at the place where execution is to occur. These might be credit institutions having certain powers with respect to property of the defendant against which execution is to be levied by decision of a court ${ }^{40}$.

The question arises as to the correlation of rules contained in the Minsk Convention and the Kiev Agreement since both treaties regulate the recognition and enforcement of foreign judgments on the territory of the CIS Member States. TN Neshataeva argues that the Minsk Convention does not extend to the enforcement of decisions of economic or arbi-

\footnotetext{
40 For a detailed analysis of Ukrainian legislation and treaties regulating the recognition and enforcement of foreign judgments, see the Decree of the Plenum of the Supreme Court of Ukraine, No. 12 "On the Practice of Consideration by Courts of Petitions on Recognition and Enforcement of Foreign Judgments and Arbitral Awards and on Awards Rendered by International Commercial Arbitral Tribunals on the Territory of Ukraine" of 24 December 1999.
} 
trazh courts with regard to disputes connected with economic activity ${ }^{41}$. She came to this conclusion on the basis of analyzing Article 82 of the Minsk Convention, which provides that it does not affect the provisions of other international treaties by which the Contracting Parties are bound. The Kiev Agreement is such a treaty, being lex specialis which regulates the resolution only of economic cases (that is, cases arising from contractual and other civil-law relations between economic subjects and from their relations with State and other agencies) (Article 1) $)^{42}$. However, the Kiev Agreement does not extend to judgments rendered on the territory of Georgia or Moldova, as these States are not parties to the Kiev Agreement. In their case, the Minsk Convention would be applicable.

It should be noted that the provisions of the Kiev Agreement and the Minsk Convention have been elaborated in another treaty specially devoted to the recognition and enforcement of judgments in economic disputes on the territory of the CIS: the Moscow Agreement of the CIS on the procedure for the Mutual Enforcement of Judgments of Arbitrazh and Economic Courts on the Territory of the CIS Member States of 6 March 1998 (hereinafter: Moscow Agreement) ${ }^{43}$. The basic purpose of the Moscow

$41 \quad$ TN Neshataeva, 'On the Recognition and Enforcement of Judgments with Regard to Economic Disputes of Courts of Member States of the CIS on the Territory of the Russian Federation' (1997) 2 Journal of Private International Law 9.

42 It should be borne in mind that the Kiev Agreement regulates the recognition and enforcement of judgments only of competent courts, that is, those courts whose competence to resolve a dispute in substance meets the criteria of the Kiev Agreement (Article 4). Thus, a court considering a dispute in substance and rendering a judgment subject to enforcement beyond the limits of its jurisdiction must possess competence in two aspects: first, to be competent according to procedural rules of the respective national legislation which regulates them; second, to be competent under Article 4 of the Kiev Agreement.

43 Информационный вестник Совета глав государств и Совета глав правительств СНГ «Содружество» (1998), no. 1. The Moscow Agreement entered into force on 9 January 2001. Russia and Ukraine are not parties. The Moscow Agreement is referring to, and by its terminology in the title expressly encompasses, the three types of special State courts which consider economic disputes in the CIS countries. Two of these types are "economic" courts for which two Russian terms are used: "хозяйственный" and "экономический". Both are translated in English as "economic", which is the most literal and accurate translation; they are widely misdescribed as "commercial" or "business" courts in some of the literature.
Agreement is to eliminate a judicial proceeding to authorize enforcement of a foreign judgment, which would mean that the enforcement of such a judgment would be equated to the enforcement proceedings of own courts in accordance with national legislation. In effect, foreign judgments for these purposes would enjoy the same status as domestic judgments.

The Moscow Agreement (Article 4) expressly provides that the priority, procedure, and limits of recovery and measures to secure the enforcement of a judgment of a competent court are determined by the legislation of the Contracting Party on whose territory recovery is to be made. Recovery is therefore on the same conditions as would obtain for the enforcement of a decision of a court of the Contracting Party; that is, national regime. Enforcement is levied against property of a debtor in accordance with the legislation of the State where the debtor is located upon the petition of the creditor to the competent court of the Contracting Party to the Moscow Agreement. The applicant must submit:

(1) a duly certified copy of a judgment of the competent court with confirmation of its entry into legal force, unless this is evident from the text of the judgment itself, whose enforcement is being petitioned for;

(2) the document of a competent court confirming the participation of the debtor in the judicial session and, if that party failed to appear, confirmation of proper notification of the time and place of the judicial session;

(3) the writ of execution.

The Moscow Agreement (Article 3) thus provides that a judgment of a competent court of one Contracting Party which has entered into legal force is enforced on the territory of another Contracting Party in an uncontested proceeding.

\section{Conclusion}

Three distinct regimes thus operate in Russia and Ukraine with respect to proceedings in cases with the participation of foreign persons. The first is within the framework of bilateral international treaties concerning legal assistance in civil, family, and criminal matters. The second is within the framework 
of multilateral treaties (Kiev Agreement and Minsk Convention, with the prospect one day, perhaps, of the Moscow Agreement).
Third is the framework of national legislation of Russia (CAP Russia) and Ukraine (CEP and CCP Ukraine).

\section{References:}

1. Campbell C. (ed.) International Civil Procedure. 2 vols. Lulu.com, 2007.

2. Epstein D., Baldwin C. International Litigation: A Guide to Jurisdiction, Practice, and Strategy. BRILL, 2010.

3. Fentiman R. International Commercial Litigation. Oxford University Press, 2010.

4. Grubbs S. (ed.) International Civil Procedure (World Law Group Series). Kluwer Law International, 2003.

5. Hartley T. C. International Commercial Litigation: Texts, Cases and Materials on Private International Law. Cambridge University Press, 2009.

6. James M. Litigation with a Foreign Aspect: A Practical Guide. Oxford University Press, 2009.

7. Kramer X.E., van Rhee C.H. (eds.) Civil Litigation in a Globalising World. T.M.C. Asser Press, 2012.

8. Lascelles G. The International Comparative Legal Guide to Litigation and Dispute Resolution 2012 (International Comparative Legal Guide Series). Global Legal Group Ltd., 2012.

9. Milmo M. (ed.) International Litigation Procedure 2012. Sweet and Maxwell, 2013.

10. Pollack C. (ed.) The International Comparative Legal Guide to Litigation and Dispute Resolution 2011 (International Comparative Legal Guide Series). Global Legal Group Ltd., 2011.

11. Vogenauer S., Hodges C. (eds). Civil Justice Systems in Europe: Implications for Choice of Forum and Choice of Contract Law (Studies of the Oxford Institute of European and Comparative Law Series). Hart Publishing, 2012.

12. Weintraub R.J. International Litigation and Arbitration: Practice and Planning (Law Casebook Series). Carolina Academic Press, 2010. 